Mook (2019)

\title{
ANSERJ
}

Vol. 10 , No. 2

Autumn / Automne 2019

pp. $81-87$

Canadian Journal of Nonprofit and Social Economy Research

Revue canadienne de recherche sur les OBSL et l'économie sociale

\section{The Sustainable Development Goals: A Tipping Point for Impact Measurement?}

\author{
Laurie Mook \\ Arizona State University
}

\begin{abstract}
This article proposes a holistic framework of integrated social accounting that could be adopted by all types of organizations in the social economy, as well as in other sectors. The impetus for this derives from the popularity of the sustainable development goals (SDGs) and the broadening of collective impact thinking. The article advances a model of integrated social accounting that brings together four dimensions: 1) resources/capitals, 2) value creation/destruction, 3) internal systems and processes, and 4) organizational learning, growth, and innovation. Organizations using this model focus on the implications of their activities through the lens of the SDGs, looking both internally and externally.
\end{abstract}

\section{RÉSUMÉ}

Cet article propose un cadre global de comptabilité sociale intégrée qui pourrait être adopté par les organisations de l'économie sociale, ainsi que dans d'autres secteurs. Cela découle de la popularité des objectifs de développement durable (ODD) et de l'élargissement de la réflexion collective en matière d'impact. L'article avance un modèle de comptabilité sociale intégrée qui regroupe quatre dimensions : 1) ressources / capitaux, 2) création / destruction de valeur, 3) systèmes et processus internes et 4) apprentissage organisationnel, croissance et innovation. Les organisations qui utilisent ce modèle se concentrent sur les implications de leurs activités dans l'optique des ODD, en cherchant à la fois en interne et en externe.

Keywords / Mots clés : Social accounting; Sustainable development goals; Balanced scorecard; Performance management; Impact measurement / Comptabilité sociale; Objectifs de développement durable; Tableau de bord équilibré; Gestion de la performance; Mesure d'impact 


\section{Mook (2019)}

\section{INTRODUCTION}

One of the complexities of impact measurement is navigating the overwhelming number of methods, indicators, and tools available to do so. With so many options, it is difficult for organizations to aggregate results to measure economic, social, and environmental performance beyond their walls. Impact reporting remains siloed and not easily connected to measuring changes over time in communities, regions, and countries.

In addition to the lack of uniformity, the very idea that social impact can be precisely measured has been challenged. This is evidenced by the many difficulties facing organizations trying to measure their impact (Mook, Maiorano, Ryan, Armstrong, \& Quarter, 2015; Ruff \& Olsen, 2016). For instance, organizations calculating a social return on investment (SROI) ratio report that social impact measurement is a highly subjective process. The complexity of calculating "deadweight" (the amount of impact that would have happened without the activity anyway), "attribution" (the percentage of impact attributable to the organization), and "drop-off" (the degree to which impacts diminish over time) adds to the subjective nature of the result (Nicholls, Lawlor, Neitzert, \& Goodspeed, 2012). Because of this, outcomes are not comparable between organizations or programs. Nevertheless, it is hard to avoid the temptation to compare.

On the positive side, undertaking an impact measurement process such as SROI results in increased dialogue and engagement with stakeholders. In turn, the knowledge gained leads to improvements in performance. Indeed, studies have found that the process of doing any evaluation at all and sticking with it were crucial factors in the success of the program evaluated (Waits, Campbell, Gau, Jacobs, Rex, \& Hess, 2006).

Building on the Nonprofit Integrated Social Accounting (NISA) model (Mook, 2014) and the popularity of the United Nations Sustainable Development Goals 2030 Agenda (United Nations, n.d., Appendix 1), a new integrated social accounting (ISA) model that expands its focus to align with societal impact is proposed. Whereas the NISA model motivates and monitors organization performance toward achieving an organization's mission, ISA focuses on both inward-facing and outward-facing organizational and societal goals using the lens of the sustainable development goals (SDGs).

This ISA model consists of four interconnected dimensions: 1) resources/capitals, 2) value creation/destruction, 3) internal systems and processes, and 4) organizational learning, growth, and innovation.

At a high level, ISA responds to the following questions:

1. Resources/capitals: What level of resources/capital does the organization need to operate effectively and efficiently in line with the SDGs to achieve its mission?

2. Value creation/destruction: What difference is the organization making economically, socially, and environmentally through the lens of the SDGs?

3. Internal systems and processes: What internal systems and processes does the organization need to have in place to successfully achieve its goals and remain viable?

4. Organizational learning, growth, and innovation: What can the organization learn from itself and its stakeholders to improve its impact on the SDGs and maintain organizational sustainability?

Through these four dimensions, organizations link performance management and impact measurement, addressing efficiency and effectiveness, functional and strategic accountability, and feedback and adjustment. The SDGs provide the common lens that allows for organizations to take collective impact ${ }^{1}$ to what Mark Cabaj and Liz Weaver (2016) argue is the next level: moving from a managerial to a movement-building perspective. 
As noted previously, there is an overwhelming number of indicators organizations can use to measure impact. Switching the paradigm of impact measurement from a positivistic one to an interpretivist one can alleviate some of the complexity: "this shifts the framing ... from calculating a precise number to generalize and predict, to understanding lived experiences to improve impact and to mobilize resources. Calculations are still important, but they are not the ends" (Mook et al., 2015, p. 237).

Flexibility is also important. There are many ways to reach a goal. This is the perspective taken by the Common Approach to Impact Measurement (2019) initiative for social enterprises led by accounting professor Kate Ruff and housed at Carleton University (Common Approach, 2019). As Ruff and Sara Olsen (2016) argue,

The market is best served when each organization can measure its social impact in the way that is most meaningful and insightful to its aim and operations, as long as it follows common principles for good measurement. Drawing insights from financial accounting, ${ }^{2}$ good analysts focus on measures that are flexible and adaptable to different contexts (within limits), applied consistently (organizations pick an approach and stick to it), and well disclosed (bring on the fine print!). (p. 2)

To help align with the SDGs, Statistics Canada, along with several other federal departments, have developed the Canadian Indicator Framework (CIF). The CIF sets out ambitions and suggestions of indicators for each of the SDGs in the Canadian context. These could be a starting point for relating the global SDGs to a local context. They provide guideposts and another step toward a shared language and shared values (Global Affairs Canada, 2018; Government of Canada, 2019a). Data hubs hosted by Statistics Canada track Canada's progress at the national level (Government of Canada, 2019b).

A single organization will not necessarily impact all SDGs but will self-align with the ones that are most material in terms of their value creation or the minimization of negative impact. Guidelines for establishing materiality are available through bodies such as the Sustainability Accounting Standards Board (SASB, 2018), the Global Reporting Initiative (GRI, 2013), and Social Value UK (2019).

To facilitate understanding and action, the SDGs can be categorized into themes. For instance, the investment firm MSCl (2016) proposes five actionable impact themes that are applicable across a broad set of stakeholders: 1) basic needs, 2) empowerment, 3) climate change, 4) natural capital, and 5) governance. Each theme is matched up to a set of SDGs (see Figure 1).

\section{MOVING FORWARD}

This article proposes the next wave of integrated social accounting, linking performance management and impact measurement through the common lens of the

\section{Figure 1: SDGs by actionable theme}

\begin{tabular}{|l|l|}
\hline Theme & Sustainable Development Goal (SDG) \\
\hline Basic Needs & 1. No poverty \\
& 2. Zero hunger \\
& 3. Good health \& well-being \\
& 6. Clean water \& sanitation, \\
& 11. Sustainable cities \& communities \\
\hline Empowerment & $\begin{array}{l}\text { 4. Quality education } \\
\text { 5. Gender equality }\end{array}$ \\
& $\begin{array}{l}\text { 8. Decent work \& economic growth } \\
\text { 9. Industry, innovation \& infrastructure }\end{array}$ \\
& 10. Reduced inequalities \\
\hline Climate Change & 7. Affordable \& clean energy \\
& 13. Climate action \\
\hline Natural Capital & 12. Responsible consumption \& production \\
& 14. Life below water \\
& 15. Life on land \\
\hline Governance & 16. Peace, justice, \& strong institutions \\
& 17. Partnerships \\
\hline
\end{tabular}




\section{Mook (2019)}

SDGs. In implementing ISA, organizations report on selected metrics associated with the SDGs to a common data hub, and these data could be used for further analysis to inform policy and resource allocation at all levels. As multiple organizations across different sectors are driven by common goals, albeit in different ways, we can move closer to accomplishing the SDG 2030 agenda.

\section{NOTES}

1. Collective impact involves organizations with a common agenda and shared measurement system working together to achieve social change (Collective Impact Forum, 2014).

2. See Ruff (2013).

\section{REFERENCES}

Cabaj, M., \& Weaver, L. (2016). Collective impact 3.0: An evolving framework for community change. Waterloo, ON: Tamarack Institute. URL: http://www.unitedwayglv.org/UnitedWay/media/PDFs/Collective_Impact_3-0_FINAL_PDF.pdf [November 10, 2019].

Collective Impact Forum (2014). What is collective impact. URL: https://www.collectiveimpactforum.org/what-collective -impact [November 19, 2019].

Common Approach. (2019). Unlocking social change through a common approach to impact measurement. Ottawa, ON: Carleton University. URL: https://sprott.carleton.ca/2019/unlocking-social-change-through-a-common -approach-to-impact-measurement/ [November 10, 2019].

Global Affairs Canada. (2018). Canada's implementation of the 2030 agenda for sustainable development. Ottawa, ON: Global Affairs Canada. URL: https://sustainabledevelopment.un.org/content/documents/20312Canada _ENGLISH_18122_Canadas_Voluntary_National_ReviewENv7.pdf [November 11, 2019].

Global Reporting Initiative. (2013). G4 Sustainability reporting guidelines implementation model. Amsterdam, NL: Global Reporting Institute. URL: https://www.globalreporting.org/resourcelibrary/GRIG4-Part2-Implementation -Manual.pdf [November 11, 2019].

Government of Canada. (2019a). Towards Canada's 2030 agenda national strategy: Interim document. Sustainable development goals. Ottawa, ON: Government of Canada. URL: https://www.canada.ca/content/dam/esdc-edsc /documents/programs/agenda-2030/7781_EmploymentSocialDevelopment_2030-ENv5.pdf [November 10, 2019].

Government of Canada (2019b). Sustainable development goals data hub. Ottawa, ON: Government of Canada. URL: https://www144.statcan.gc.ca/sdg-odd/index-eng.htm [November 10, 2019].

Mook, L. (2014). An integrated social accounting model for nonprofit organizations. Advances in Public Interest Accounting, 17, 197-221.

Mook, L., Maiorano, J., Ryan, S., Armstrong, A., \& Quarter, J. (2015). Turning social return on investment on its head: The stakeholder impact statement. Nonprofit Management and Leadership, 26(2), 229-246.

MSCI. (2016). MSCI ESG sustainable impact metrics. URL: https://www.msci.com/documents/1296102/1636401/ESG _ImpactMetrics-2016.pdf/0902a64f-af8d-4296-beaa-d105b7d74dc3 [November 11, 2019].

Nicholls, J., Lawlor, E., Neitzert, E., \& Goodspeed, T. (2012). A guide to social return on investment (2nd ed.). URL: http://www.socialvalueuk.org/app/uploads/2016/03/The\%20Guide\%20to\%20Social\%20Return\%20on\%20 Investment\%202015.pdf [November 11, 2019].

Ruff, K. (2013). The role of intermediaries in social accounting: Insights from effective transparency systems. In L. Mook (Ed.), Accounting for social value (pp. 230-248). Toronto, ON: University of Toronto Press.

Ruff, K., \& Olsen, S. (2016). The next frontier in social impact measurement isn't measurement at all. Stanford Social Innovation Review. URL: https://ssir.org/articles/entry/next_frontier_in_social_impact_measurement [November 10, 2019]. 


\section{Mook (2019)}

Social Value UK. (2019). What are the principles of social value? Liverpool, UK: Social Value UK. URL: http://www .socialvalueuk.org/what-is-social-value/the-principles-of-social-value/ [November 11, 2019].

Sustainability Accounting Standards Board. (2018). SASB materiality map. San Francisco, CA: Sustainability Accounting Standards Board (SASB). URL: from https://materiality.sasb.org/ [November 11, 2019].

United Nations. (n.d.). Sustainable development goals. New York, NY: United Nations. URL: https://sustainable development.un.org/sdgs [November 7, 2019].

Waits, M.J., Campbell, H.E., Gau, R., Jacobs, E., Rex, T., \& Hess, R.K. (2006). Why some schools with Latino children beat the odds ... and others don't. Phoenix, AZ: Morrison Institute for Public Policy and Arizona State University. URL: https://files.eric.ed.gov/fulltext/ED499748.pdf [November 11, 2019].

\section{ABOUT THE AUTHOR / L'AUTEUR}

Laurie Mook is Associate Professor, School of Community Resources and Development at Arizona State University, 411 N Central Ave, Suite 550, Phoenix, AZ 85004, United States. Email: Imook@asu.edu. 
Mook (2019)

\section{APPENDIX A: SUSTAINABLE DEVELOPMENT GOALS}

\begin{tabular}{|c|c|c|c|}
\hline Goal & & & Ambitions \\
\hline 1 & No poverty & End poverty in all its forms everywhere & Reduce poverty in Canada in all its forms \\
\hline 2 & Zero hunger & $\begin{array}{l}\text { End hunger, achieve food security and } \\
\text { improved nutrition and promote sustainable } \\
\text { agriculture }\end{array}$ & $\begin{array}{l}\text { Canadians have access to sufficient, affordable } \\
\text { and nutritious food } \\
\text { Canadian agriculture is sustainable }\end{array}$ \\
\hline 3 & $\begin{array}{l}\text { Good health } \\
\text { and well-being }\end{array}$ & $\begin{array}{l}\text { Ensure healthy lives and promote well-being } \\
\text { for all at all ages }\end{array}$ & $\begin{array}{l}\text { Canadians adopt healthy behaviours } \\
\text { Canadians have healthy and satisfying lives } \\
\text { Canada prevents causes of premature death }\end{array}$ \\
\hline 4 & $\begin{array}{l}\text { Quality } \\
\text { education }\end{array}$ & $\begin{array}{l}\text { Ensure inclusive and equitable quality } \\
\text { education and promote lifelong learning } \\
\text { opportunities for all }\end{array}$ & $\begin{array}{l}\text { Canadians have access to inclusive and quality } \\
\text { education throughout their lives }\end{array}$ \\
\hline 5 & Gender equality & $\begin{array}{l}\text { Achieve gender equality and empower all } \\
\text { women and girls }\end{array}$ & $\begin{array}{l}\text { Canadians are well represented at all levels of } \\
\text { decision making } \\
\text { Canadians share responsibilities within } \\
\text { households and families }\end{array}$ \\
\hline 6 & $\begin{array}{l}\text { Clean water and } \\
\text { sanitation }\end{array}$ & $\begin{array}{l}\text { Ensure availability and sustainable } \\
\text { management of water and sanitation for all }\end{array}$ & $\begin{array}{l}\text { Canadians have access to drinking water and } \\
\text { use it in a sustainable manner }\end{array}$ \\
\hline 7 & $\begin{array}{l}\text { Affordable and } \\
\text { clean energy }\end{array}$ & $\begin{array}{l}\text { Ensure access to affordable, reliable, } \\
\text { sustainable and modern energy for all }\end{array}$ & $\begin{array}{l}\text { Canadians reduce their energy consumption } \\
\text { Canadians have access to clean and renewable } \\
\text { energy }\end{array}$ \\
\hline 8 & $\begin{array}{l}\text { Decent work } \\
\text { and economic } \\
\text { growth }\end{array}$ & $\begin{array}{l}\text { Promote sustained, inclusive and sustainable } \\
\text { economic growth, full and productive } \\
\text { employment and decent work for all }\end{array}$ & $\begin{array}{l}\text { Canadians have access to quality jobs } \\
\text { Canadians contribute to and benefit from } \\
\text { sustainable economic growth }\end{array}$ \\
\hline 9 & $\begin{array}{l}\text { Industry, } \\
\text { innovation and } \\
\text { infrastructure }\end{array}$ & $\begin{array}{l}\text { Build resilient infrastructure, promote inclusive } \\
\text { and sustainable industrialization and foster } \\
\text { innovation }\end{array}$ & $\begin{array}{l}\text { Canada fosters sustainable research and } \\
\text { innovation } \\
\text { Canadians have access to modern and } \\
\text { sustainable infrastructures }\end{array}$ \\
\hline 10 & $\begin{array}{l}\text { Reduced } \\
\text { inequality }\end{array}$ & Reduce inequality within and among countries & $\begin{array}{l}\text { Canadians live free of discrimination and } \\
\text { inequalities are reduced }\end{array}$ \\
\hline 11 & $\begin{array}{l}\text { Sustainable } \\
\text { cities and } \\
\text { communities }\end{array}$ & $\begin{array}{l}\text { Make cities and human settlements inclusive, } \\
\text { safe, resilient and sustainable }\end{array}$ & $\begin{array}{l}\text { Canadians have access to quality housing } \\
\text { Canadians live in healthy, accessible, and } \\
\text { sustainable cities and communities }\end{array}$ \\
\hline 12 & $\begin{array}{l}\text { Responsible } \\
\text { consumption } \\
\text { and production }\end{array}$ & $\begin{array}{l}\text { Ensure sustainable consumption and } \\
\text { production patterns }\end{array}$ & Canadians consume in a sustainable manner \\
\hline 13 & Climate action & $\begin{array}{l}\text { Take urgent action to combat climate change } \\
\text { and its impacts* }\end{array}$ & $\begin{array}{l}\text { Canadians reduce their } \mathrm{GHG} \text { emissions } \\
\text { Canadians are well-equipped and resilient to } \\
\text { face the effects of climate change }\end{array}$ \\
\hline
\end{tabular}


Mook (2019)

\section{APPENDIX A: (continued)}

\begin{tabular}{|l|l|l|l|}
\hline Goal & & & Ambitions* \\
\hline 14 & Life below water & $\begin{array}{l}\text { Conserve and sustainably use the oceans, } \\
\text { seas and marine resources for sustainable } \\
\text { development }\end{array}$ & $\begin{array}{l}\text { Canada protects and conserves marine areas } \\
\text { and sustainably manages ocean fish stocks }\end{array}$ \\
\hline 15 & Life on land & $\begin{array}{l}\text { Protect, restore and promote sustainable use } \\
\text { of terrestrial ecosystems, sustainably manage } \\
\text { forests, combat desertification, and halt and } \\
\text { reverse land degradation and halt biodiversity } \\
\text { loss }\end{array}$ & $\begin{array}{l}\text { Canada ensures all species have a healthy and } \\
\text { viable population } \\
\text { Canada conserves and restores ecosystems } \\
\text { and habitat } \\
\text { Canada sustainably manages forests, lakes and } \\
\text { rivers }\end{array}$ \\
\hline 16 & $\begin{array}{l}\text { Peace and } \\
\text { justice strong } \\
\text { institutions }\end{array}$ & $\begin{array}{l}\text { Promote peaceful and inclusive societies for } \\
\text { sustainable development, provide access to } \\
\text { justice for all and build effective, accountable } \\
\text { and inclusive institutions at all levels }\end{array}$ & $\begin{array}{l}\text { Canadians are safe and secure, in person and } \\
\text { online } \\
\text { Canadians have equal access to justice } \\
\text { Canadians are supported by effective, } \\
\text { accountable, and transparent institutions }\end{array}$ \\
\hline 17 & $\begin{array}{l}\text { Partnerships to } \\
\text { achieve the goal }\end{array}$ & $\begin{array}{l}\text { Strengthen the means of implementation and } \\
\text { revitalize the global partnership for sustainable } \\
\text { development }\end{array}$ & $\begin{array}{l}\text { Canada fosters collaboration and partnerships } \\
\text { to advance the SDGs }\end{array}$ \\
\hline
\end{tabular}

"Source: Government of Canada (2019a) 